Atmos. Chem. Phys., 13, 11089-11099, 2013

www.atmos-chem-phys.net/13/11089/2013/

doi:10.5194/acp-13-11089-2013

(c) Author(s) 2013. CC Attribution 3.0 License.

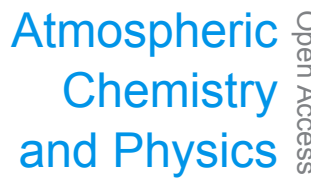

\title{
Low-level jet characteristics over the Arctic Ocean in spring and
} summer

\author{
L. Jakobson ${ }^{1}$, T. Vihma ${ }^{2}$, E. Jakobson ${ }^{3,4}$, T. Palo ${ }^{1}$, A. Männik ${ }^{5}$, and J. Jaagus ${ }^{1}$ \\ ${ }^{1}$ Department of Geography, University of Tartu, Vanemuise 46, 51014, Tartu, Estonia \\ ${ }^{2}$ Finnish Meteorological Institute, P.O. Box 503, 00101, Helsinki, Finland \\ ${ }^{3}$ Tartu Observatory, 61602, Tõravere, Tartumaa, Estonia \\ ${ }^{4}$ Department of Physics, University of Tartu, Tähe 4, 51010, Tartu, Estonia \\ ${ }^{5}$ Estonian Meteorological and Hydrological Institute, Mustamäe tee 33, 10616, Tallinn, Estonia
}

Correspondence to: L. Jakobson (liisi.jakobson@ut.ee)

Received: 30 November 2012 - Published in Atmos. Chem. Phys. Discuss.: 22 January 2013

Revised: 26 August 2013 - Accepted: 15 October 2013 - Published: 14 November 2013

\begin{abstract}
Low-level jets (LLJ) are important for turbulence in the stably stratified atmospheric boundary layer, but their occurrence, properties, and generation mechanisms in the Arctic are not well known. We analysed LLJs over the central Arctic Ocean in spring and summer 2007 on the basis of data collected in the drifting ice station Tara. Instead of traditional radiosonde soundings, data from tethersonde soundings with a high vertical resolution were used. The Tara results showed a lower occurrence of LLJs $(46 \pm 8 \%)$ than many previous studies over polar sea ice. Strong jet core winds contributed to growth of the turbulent layer. Complex relationships between the jet core height and the temperature inversion top height were detected: substantial correlation $(r=0.72 ; p<0.01)$ occurred when the jet core was above the turbulent layer, but when inside the turbulent layer there was no correlation. The most important forcing mechanism for LLJs was baroclinicity, which was responsible for the generation of strong and warm LLJs, which on average occurred at lower altitudes than other jets. Baroclinic jets were mostly associated with transient cyclones instead of the climatological air temperature gradients. Besides baroclinicity, cases related to inertial oscillations and gusts were detected. As many as $49 \%$ of the LLJs observed were associated with a frontal passage, which provides favourable conditions for baroclinicity, inertial oscillations, and gusts. Further research needs on LLJs in the Arctic include investigation of low-level jet streams and their effects on the sea ice drift and atmospheric moisture transport.
\end{abstract}

\section{Introduction}

Numerous recent studies have demonstrated major changes in the climate system of the central Arctic. Air temperatures have increased (e.g. Walsh et al., 2011) and the sea ice melt season has become longer (Maksimovich and Vihma, 2012). Sea ice has become thinner, its drift velocities have increased, and its extent has strongly decreased in summer and autumn (Stroeve et al., 2012). Arctic warming during the 21st century is very likely to exceed the global mean warming but, simultaneously, the scatter between various climate model projections for the 21st century is particularly large in the Arctic (Christensen et al., 2007). Further, climate models have large problems in simulating the recent changes in the Arctic sea ice cover (Stroeve et al., 2007), and even atmospheric reanalyses include major errors over the Arctic sea ice (Jakobson et al., 2012).

Errors in both climate models (Tjernström et al., 2005) and numerical weather prediction models (Atlaskin and Vihma, 2012) tend to be largest in conditions of a stable boundary layer (SBL). There are several reasons that make SBL a challenge for models (Steeneveld et al., 2006; Atlaskin and Vihma, 2012). One of them is related to the low-level jet (LLJ, a low-altitude maximum in the vertical profile of the wind speed), which commonly occurs in conditions of a SBL. In a SBL, turbulence near the Earth surface is weak. Hence, the wind shear below the core of a LLJ may be the main source of turbulence (Mahrt, 2002; Mäkiranta et al., 2011). This results in a top-down structure of the SBL, but 
the model parameterizations are not designed for such conditions. Further, a LLJ often occurs intermittently, so that the shear-driven turbulence is also intermittent, which is another major challenge for models (Mahrt, 2002; Costa et al., 2011). A LLJ is often detected only as a maximum in the vertical wind profile, without any particular three-dimensional structure. Some LLJs are, however, associated with a narrow horizontal zone of a high-speed flow, called a low-level jet stream (Stensrud, 1996).

In the Arctic Ocean, LLJs may also affect the motion of the sea ice margin (Langland et al., 1989), which further affects the sea ice mass balance. There are, however, not many detailed studies on the occurrence and generation mechanisms of LLJs over the Arctic sea ice. Near the coasts of Greenland and Svalbard, LLJs are often related to katabatic winds (Heinemann, 2004; Vihma et al., 2011) or more complex orographic effects (Samelson and Barbour, 2008; Esau and Repina, 2012). LLJs are also common over sea ice far from orographic influence: Langland et al. (1989) observed LLJs related to an ice breeze - a sea-breeze-type mesoscale circulation. Vihma et al. (1998) observed LLJs over the ice edge zone in the Denmark Strait; the strongest LLJs were generated by baroclinicity. Andreas et al. (2000) observed a high frequency of occurrence ( $80 \%$ ) of LLJs over the Antarctic sea ice zone, and suggested that they were primarily due to inertial oscillations: a mechanism analogous to the classical nocturnal jet (Blackadar, 1957; Thorpe and Guymer, 1977), but in the Antarctic related to synoptic-scale changes in the atmospheric boundary layer (ABL) stratification. Inertial oscillations generated by spatial changes in surface roughness and stratification may also generate LLJs, as observed by Smedman et al. (1993) and Vihma and Brümmer (2002) in the Baltic Sea. Also ReVelle and Nilsson (2008) associated LLJs to inertial oscillations. They observed a LLJ in some $2 / 3$ of all rawinsonde soundings during a three-month-long Arctic Ocean expedition in summer 1996.

Insufficiency of high-resolution data on the vertical profiles of wind speed is the largest impediment for exploring LLJs over the Arctic Ocean. Rawinsonde soundings are only taken during cruises of a few research vessels (Lüpkes et al., 2010; Tjernström et al., 2012), most of the cruises lasting no more than approximately one month in the sea ice zone. Radiosonde soundings have been made on board the Russian drifting ice stations since 1950s, but decades ago the data quality and vertical resolution were not sufficient to yield good statistics of LLJs. Tethersonde soundings, providing a better vertical resolution, were carried out over the Antarctic sea ice in 1992 (Andreas et al., 2000) and over the Arctic sea ice in 1997-1998 during the drifting station Surface Heat Budget of the Arctic Ocean (SHEBA, Uttal et al., 2002) and during the three-week-long drift of the Arctic Ocean Expedition 2001 (Tjernström et al., 2004).

The next major tethersonde sounding campaign over the Arctic sea ice took place during the drifting ice station Tara in spring and summer 2007 (Gascard et al., 2008; Vihma et

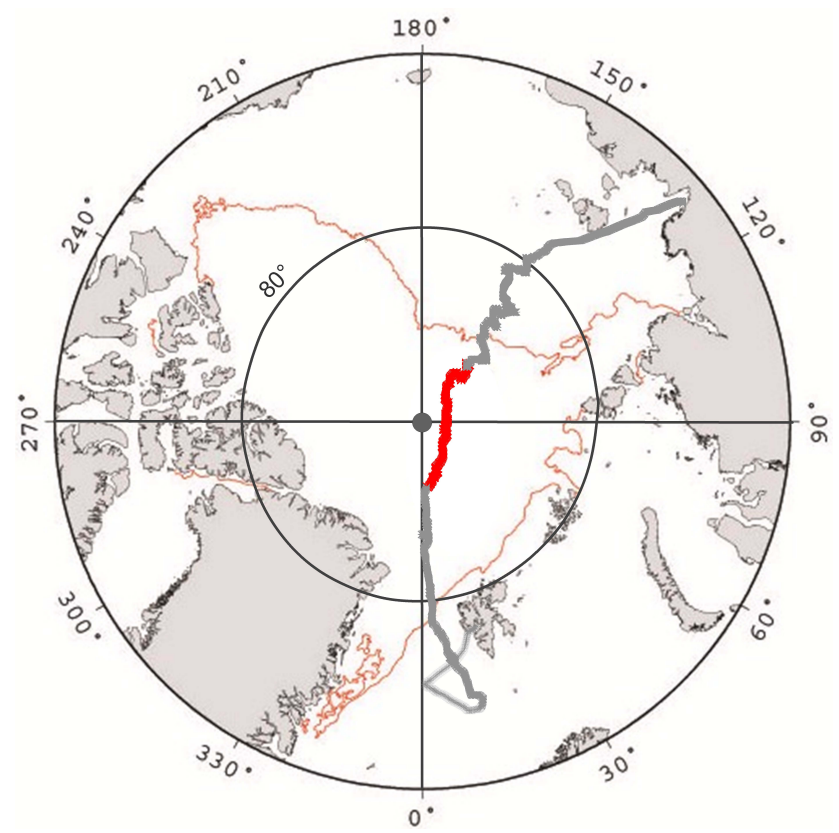

Fig. 1. Drift trajectory of Tara (red) from the period of tethersonde soundings: 25 April to 31 August 2007. The brown line shows the September minimum sea ice extent.

al., 2008); the data collected forms the basis of our study. The objective of this paper is to quantify characteristics of LLJs over the Arctic Ocean in spring and summer and to find out their most important formation mechanisms. Some mechanisms that elsewhere generate jets (e.g. terrain effects and the diurnal cycle) are not active over a flat sea ice surface very close to the North Pole. The potential generation mechanisms include baroclinicity, inertial oscillations, and gusts; these will be studied in detail.

\section{Observations and methods}

\subsection{Field observations}

Meteorological observations from the drifting ice station Tara were carried out in the central Arctic Ocean from March to September 2007 (Fig. 1). The tethersonde sounding period lasted from 25 April to 31 August. Soundings were made as regularly as possible, depending on the weather conditions and technical possibilities, at least twice a week; the average pause between two sounding days was three days (Fig. 2). There were, however, three weeks with only one sounding day per week (because of too strong wind) and one week without any soundings (because of technical problems). In consequence of two $24 \mathrm{~h}$-long intensive measurement periods, there were more soundings in July. Also, there was one $24 \mathrm{~h}$ measurement period in May and another one in June. In April there were few soundings because the first sounding 


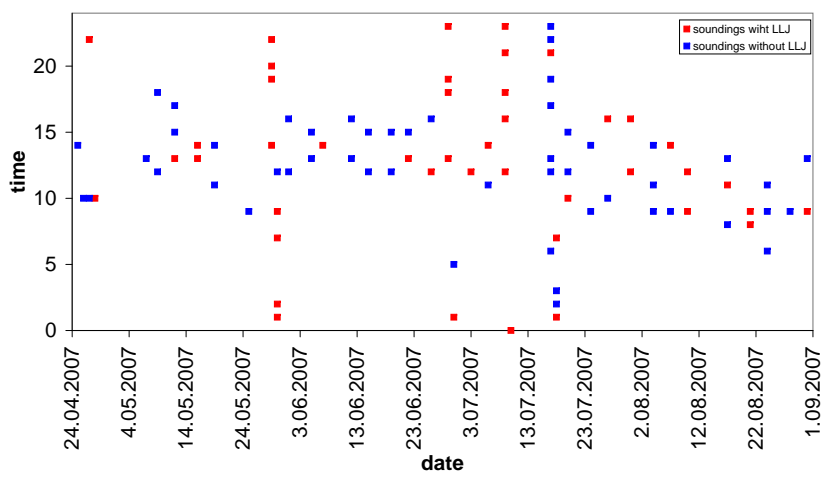

Fig. 2. Temporal distribution of Tara soundings from 25 April to 31 August, 2007. Soundings with a LLJ are marked with red and without a LLJ with blue.

day was only on 25 April. An overall $57 \%$ of soundings were made between 07:00 and 12:00 LST.

A Vaisala DigiCORA Tethersonde System was used to measure the vertical profiles of the wind speed, air temperature, relative humidity, and wind direction (Vihma et al., 2008). In this study we focus on the wind profile, but information on the temperature profile is also used to interpret the wind conditions. Our tethersonde system consisted of a $7 \mathrm{~m}^{3}$ balloon filled with helium, tether line, winch, and three sondes with $20 \mathrm{~m}$ vertical intervals. Due to the risk of breaking the balloon or tether line, the measurements were only carried out under wind speeds lower than $15 \mathrm{~m} \mathrm{~s}^{-1}$ in the whole profile. The balloon was ascended as high as possible (the average top height of the soundings was $1240 \mathrm{~m}$ ), and the data were recorded with about $5 \mathrm{~m}$ intervals. Though the winch was spooling with constant speed of 1 to $1.5 \mathrm{~m} \mathrm{~s}^{-1}$, the balloon did not gain height with a constant speed. The balloon did not rise up straight but drifted along the wind. Hence, the recorded wind speed values were systematically higher during descent than ascent (usually from 0.5 to $2 \mathrm{~m} \mathrm{~s}^{-1}$ ). Therefore, an average profile was calculated (for each sensor separately) on the basis of the ascending and descending profiles. This averaging (over every $20 \mathrm{~m}$ ) yields more reliable results, although some information on temporal variations is lost.

Due to the vicinity of the geomagnetic pole, the observed wind direction was very sensitive to even a small tilt of the compass, which was inevitable in the tethersonde system (the three vanes often showed different wind directions although the digital compasses were calibrated before every sounding). Hence, the wind direction results from tethersonde system were not used for detailed analysis.

In addition to tethersonde soundings, the air temperature and wind speed were measured at a $10 \mathrm{~m}$ high weather mast (Aanderaa AWS 2700) at the heights of 1,2,5 and $10 \mathrm{~m}$, the air relative humidity at $2 \mathrm{~m}$ and wind direction at $10 \mathrm{~m}$.

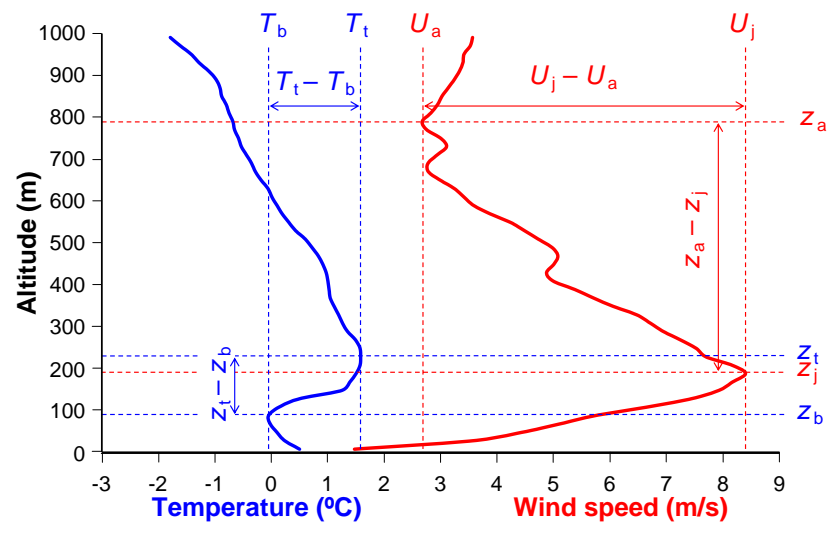

Fig. 3. Example of a tethersonde sounding at 13:00 UTC on $10 \mathrm{Au}-$ gust 2007. The variables plotted are wind speed and temperature, provided as an illustration of the definitions used.

\subsection{Jet definitions and analyses}

A LLJ was defined following Stull (1988) as the level with a local wind speed maximum of more than $2 \mathrm{~m} \mathrm{~s}^{-1}$ greater than wind speeds above it. The level of maximum wind was defined as the jet core $\left(z_{\mathrm{j}}\right)$. The difference between $z_{\mathrm{j}}$ and the subsequent wind speed minimum above $\left(z_{\mathrm{a}}\right)$ was defined as the jet depth $\left(z_{\mathrm{a}}-z_{\mathrm{j}}\right)$. The wind speed difference between the core speed $\left(U_{\mathrm{j}}\right)$ and the minimum speed above $\left(U_{\mathrm{a}}\right)$ was defined as the jet strength $\left(U_{\mathrm{j}}-U_{\mathrm{a}}\right)$. The level of maximum air temperature was defined as the temperature inversion top $\left(z_{\mathrm{t}}\right)$. The difference between the $z_{\mathrm{t}}$ and the previous temperature minimum below $\left(z_{\mathrm{b}}\right)$ was defined as the temperature inversion depth $\left(z_{\mathrm{t}}-z_{\mathrm{b}}\right)$. The air temperature difference between the inversion top temperature $\left(T_{\mathrm{t}}\right)$ and the minimum temperature below $\left(T_{\mathrm{b}}\right)$ was defined as the temperature inversion strength $\left(T_{\mathrm{t}}-T_{\mathrm{b}}\right)$. Figure 3 illustrates these variables. In the illustrated example sounding from 10 August 2007, the data allow identifying a LLJ in the wind speed profile with a core speed of $8.4 \mathrm{~m} \mathrm{~s}^{-1}$ at the height of $18 \mathrm{~m}$. The wind is remarkably weak near the surface and around $800 \mathrm{~m}$. The inversion $(230 \mathrm{~m})$ is slightly above the jet core $(180 \mathrm{~m})$. The inversion strength is only $1.6^{\circ} \mathrm{C}$, but the jet strength $\left(5.7 \mathrm{~m} \mathrm{~s}^{-1}\right)$ is larger than the average observed at Tara.

In the sounding period from 25 April to 31 August, there were a total of 95 soundings in 39 sounding days. For LLJ statistics, one sounding per day was selected. Such a selection was needed because the LLJs observed were not necessarily independent of each other (up to eight soundings per day were made). To count the occurrence of LLJs, the highest sounding per day was chosen; 18 of these 39 cases, i.e. $46 \%$, included a LLJ. Due to the limited sample, the standard uncertainty of the occurrence was $8 \%$, assuming binormal distribution (in addition, the occurrence naturally depends on the threshold for the jet strength; using 1.5 and $3 \mathrm{~m} \mathrm{~s}^{-1}$ the occurrence was 62 and $23 \%$, respectively, but $2 \mathrm{~m} \mathrm{~s}^{-1}$ has been commonly used in previous studies). To count the other 

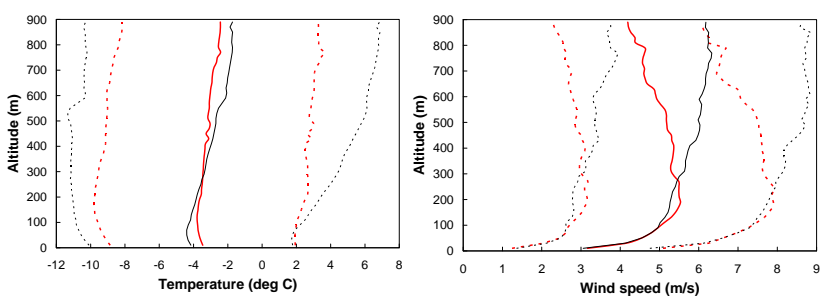

Fig. 4. The average profiles of (a) air temperature, and (b) wind speed based on all 43 profiles with LLJs observed (red) and on the 52 profiles without a LLJ (black). The dotted lines indicate the mean \pm standard deviation.

properties of LLJ, the existence of a LLJ was the criteria for choosing the daily sounding (one or more LLJs were observed in 25 of the 39 days). From sounding days with more than one LLJ observed, the highest sounding with a LLJ was chosen. All the observed LLJ profiles were used in analyses of the generation mechanisms of LLJs (43 profiles among 95 soundings). To summarize, we had a total of 95 soundings, LLJs observed in 43 of these, and 25 soundings were included in analyses of LLJ properties.

The bulk Richardson Number (Ri), which is a nondimensional parameter describing the ratio of buoyancy and wind shear in turbulence production (e.g. Kaimal and Finnigan, 1994), was used to represent static stability. As Andreas et al. (2000), we calculated $R i$ from the surface to each observation height:

$R i(z)=\frac{g z}{\Theta(z)} \frac{\Theta(z)-\Theta_{\mathrm{s}}}{v^{2}(z)}$

where $g$ is the acceleration of gravity; $z$ is the observation height; $\Theta(z)$ and $v(z)$ are the potential temperature and wind speed at $z$; and $\Theta_{\mathrm{s}}$ is the potential temperature at the height of $10 \mathrm{~m}$, which was the first averaging height of the tethersonde data (in cases of LLJs, the $10 \mathrm{~m}$ temperature was within $\pm 0.3^{\circ} \mathrm{C}$ of the $1 \mathrm{~m}$ temperature recorded in the weather mast). If $\operatorname{Ri}(z)$ was smaller than the critical Richardson number $\left(R i_{\mathrm{cr}}\right)$, the layer up to the height $z$ was considered to be turbulent. The $R i_{\text {cr }}$ has no unambiguous value; empirically based suggestions in the literature range from 0.2 to 1.0 (Galperin et al., 2007). We took $R i_{\text {cr }}=0.4$, similarly to Andreas et al. (2000). The lowest level for which $\operatorname{Ri}(z) \geq R i_{\mathrm{cr}}$ is indicated as $z_{R i}$ and is assumed to be the top of the turbulent layer.

The average wind profile plus/minus standard deviation, based on 43 soundings (all LLJs), is shown in Fig. 4. The mean profile includes a wind maximum at the height of $200 \mathrm{~m}$, but it does not meet the criterion for a LLJ. There is no significant difference in stability between the cases with and without a LLJ (not shown).

\subsection{Supporting material and analyses}

We applied the operational analyses of the European Centre for Medium-Range Weather Forecasts (ECMWF) to calculate air temperature gradients and the thermal wind, and to help in detecting fronts. We also applied the METEX backward trajectory calculator (http://db.cger.nies.go.jp/metex/ trajectory.html), which utilizes the NCEP/NCAR reanalyses, to calculate $72 \mathrm{~h}$ backward trajectories for the LLJ cases observed.

\section{Generation mechanisms of low-level jets}

As mentioned, a low-level jet in the wind profile was detected in 43 of the 95 soundings. All the observed LLJ profiles were applied in analyses of the generation mechanisms. LLJs can be generated by a variety of mechanisms, including (a) baroclinicity, (b) inertial oscillations due to temporal and spatial variations in the surface friction, (c) directional shear of other origin, (d) mesoscale circulations such as an ice breeze, and (e) gusts.

\subsection{Baroclinicity}

The baroclinicity related to a horizontal temperature gradient may generate a LLJ at the level above which the decreasing geostrophic wind dominates and below which the effect of surface friction dominates. Air temperature fields based on the ECMWF operational analyses were used to identify the cases with geostrophic wind speed decreasing with height. The equations for thermal wind are as follows (e.g. Stull, 2009):

$\frac{\partial U_{\mathrm{g}}}{\partial z}=-\frac{g}{f_{\mathrm{c}} T} \frac{\partial T}{\partial y}$
$\frac{\partial V_{\mathrm{g}}}{\partial z}=+\frac{g}{f_{\mathrm{c}} T} \frac{\partial T}{\partial x}$

where $U_{\mathrm{g}}$ is the eastward and $V_{\mathrm{g}}$ the northward component of geostrophic wind; $f_{\mathrm{c}}$ is the Coriolis parameter; $T$ is the temperature; $x$ and $y$ are coordinates towards east and north, respectively. The geostrophic wind speed at the surface and $z_{\mathrm{a}}$ were calculated. If the geostrophic wind speed was at least $2 \mathrm{~m} \mathrm{~s}^{-1}$ smaller at $z_{\mathrm{a}}$ than at the surface, the baroclinicity criterion was fulfilled. Thirteen cases (of 43) fulfilled the criteria; three of these cases were also detected as potentially generated by inertial oscillations (see below).

For baroclinic jets, the mean jet strength $\left(U_{\mathrm{j}}-U_{\mathrm{a}}\right)$ was $0.9 \mathrm{~m} \mathrm{~s}^{-1}$ larger than for jets which had no baroclinicity forcing mechanism (the difference is significant at the confidence level $p<0.05)$. The mean inversion base temperature $\left(T_{\mathrm{b}}\right)$ and inversion top temperature $\left(T_{\mathrm{t}}\right)$ were respectively $6.3^{\circ} \mathrm{C}$ and $6.2^{\circ} \mathrm{C}$ higher $(p<0.01)$ than for jets which had no baroclinicity forcing mechanism. The mean $z_{\mathrm{j}}$ of baroclinic jets $(265 \mathrm{~m})$ occurred $172 \mathrm{~m}$ lower than in the case of other jets 

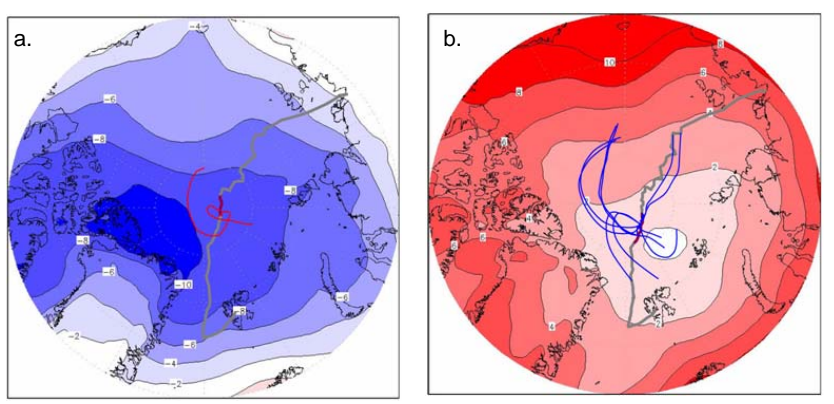

Fig. 5. The seasonal mean $925 \mathrm{hPa}$ temperature field in (a) AprilJune and (b) July-August, based on the ECMWF operational analyses. The $72 \mathrm{~h}$ backward trajectories of baroclinic LLJs detected during these periods are marked by red (two cases in April-June) or blue curves ( 11 cases in July-August). The drift track of Tara is marked in gray with the sounding period highlighted in red.

$(p<0.01)$. The baroclinicity forcing mechanism was more important in July and August (11 cases) than in April-June (two cases).

Comparisons of instantaneous and seasonal mean pressure and temperature fields, based on the ECMWF operational analyses, showed that the baroclinic LLJs were related to transient cyclones. Also the seasonal mean temperature fields at $925 \mathrm{hPa}$ level (altitude where baroclinicity typically reduced the geostrophic wind speed) included horizontal gradients in the study region, but these were not large enough or did not have the correct orientation to generate LLJs at the observation site (Fig. 5). If the baroclinic LLJs were due to the seasonal mean temperature field, the trajectories (at least their later parts before reaching Tara) should be aligned parallel to the isotherms so that cold air lies on the right of the wind vector, but this was the case only once in July-August and never in April-June (Fig. 5).

To compare the level of baroclinicity between cases with and without a LLJ, we calculated for all sounding times the geostrophic wind difference between the surface and $1 \mathrm{~km}$ height. The results showed that baroclinicity was twice as common in cases of a LLJ as in cases without a LLJ.

\subsection{Inertial oscillations}

Inertial oscillations related to the Coriolis force and ceasing of frictional drag may induce a LLJ later at night (Blackadar, 1957) or after storms, when the stable stratification is re-established (Andreas et al., 2000). To distinguish LLJs generated by inertial oscillations, one could study the history of stratification, as the occurrence of an inertial LLJ should be preceded by a period of neutral or unstable stratification. It is, however, not well known how long inertial oscillations may persist before being damped (i.e. how far in the history we should look at). Further, the neutral or unstable stratification may have occurred far from the sounding site. Hence, we only paid attention to the jet core height.
LLJs generated by inertial oscillations typically have their core close to the top of the stable boundary layer (Thorpe and Guymer, 1977; Andreas et al., 2000). As it is not possible to give an exact criteria for the threshold stratification for occurrence of turbulence, we classify as potentially inertial those jets that have their core above the lowest level where $R i \geq 0.2$ but below the lowest level where $R i \geq 0.7$. Among our 43 detected LLJs, seven cases fulfilled this criterion. It has to be mentioned that this criterion does not really prove the LLJ to be generated by inertial oscillation. Hence, we name these LLJs potentially generated by inertial oscillation. Note that LLJs generated by other forcing mechanisms may also have their core heights in the above-mentioned layer. In fact, three of the seven cases were also detected as baroclinic. Jets that were potentially generated by inertial oscillation had $1.5 \mathrm{~m} \mathrm{~s}^{-1}$ higher $(p<0.05)$ wind speed at jet core $\left(U_{\mathrm{j}}\right)$ than jets which had no inertial oscillation forcing mechanism.

We had three inertial-oscillation cases where also another sounding was done after $2-4 \mathrm{~h}$ with no jet. Such a temporal evolution of the LLJ indeed supports the diagnosis of inertial oscillations, because the jets related to synoptic-scale baroclinicity usually do not disappear so quickly. These three jets were not related to gusts (see Sect. 3.3 for the detection method).

We also studied the possibility of LLJs generated by inertial oscillations due to a spatial change in surface friction, as observed by Vihma and Brümmer (2002). The travel time of air mass between the sea ice margin and Tara was calculated. Theoretically, the maximum LLJ occurs after slightly less than half of the inertial period (Blackadar, 1957), and the next maxima occur during the second, third, and fourth oscillations, i.e. after approximately $1.4,2.4$, and 3.4 times the inertial period. There were four cases of LLJs when the air mass traveled from the open Fram Strait, thus experiencing an increase in stability at the ice margin. These LLJ occurred, however, at times that did not match the theory.

\subsection{Gusts}

Wind gusts are typically generated by downward turbulent transport of momentum from higher altitudes (Suomi et al., 2012). Hence, in a tethersonde-based individual wind profile, a wind speed maximum at some layer may be simply due to a wind gust. This was studied by comparing the ascending and descending profiles (their time difference at the jet core height was never larger than $1 \mathrm{~h}$ ). If a jet is only present in one of them, it suggests the influence of a gust. The data included four LLJs with the wind gust as the probable generation mechanism.

\subsection{Fronts}

We do not consider a front as a causal generation mechanism for LLJs, but a front is a favourable environment for LLJ generation. This is because (a) non-occluded fronts are 

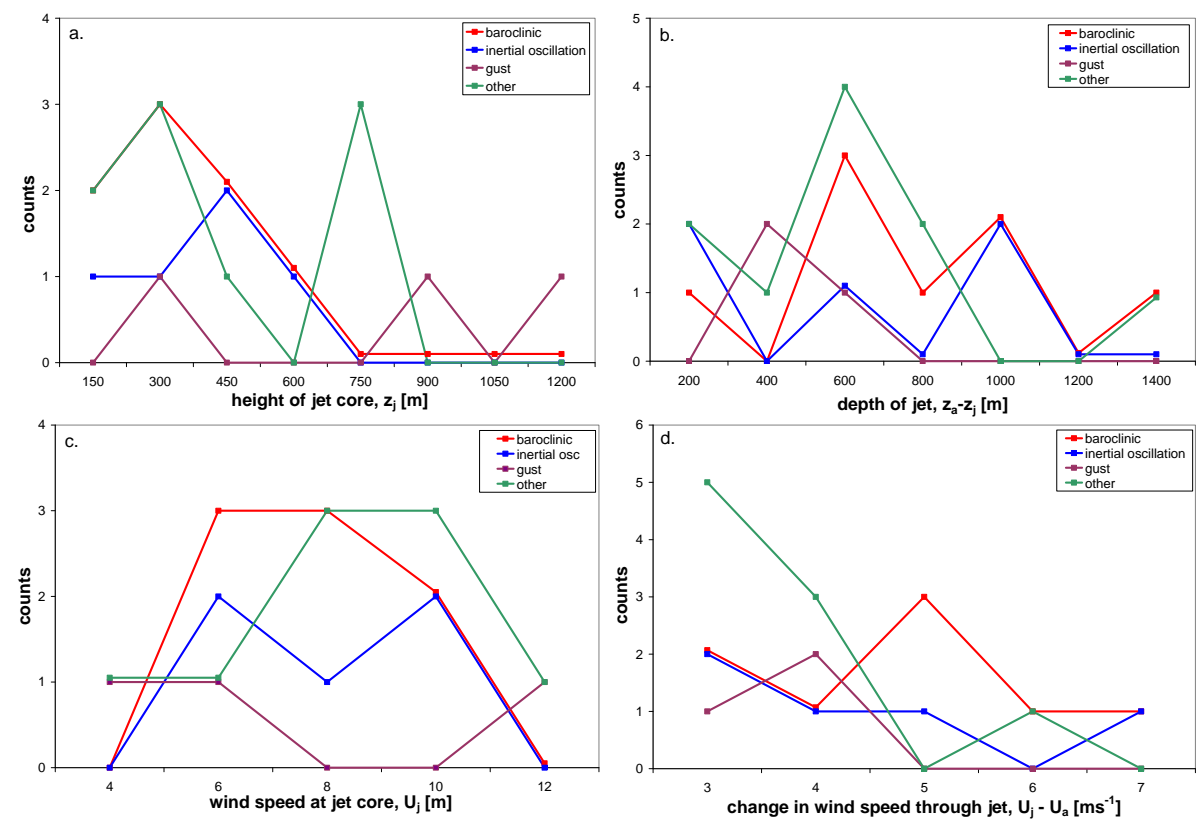

Fig. 6. Summary of the LLJ properties (indicated as counts): (a) the height of the jet core $\left(z_{\mathrm{j}}\right)$, (b) the depth of the jet $\left(z_{\mathrm{a}}-z_{\mathrm{j}}\right)$, (c) the wind speed at the jet core $\left(U_{\mathrm{j}}\right)$, and $(\mathbf{d})$ the change in wind speed through the jet $\left(U_{\mathrm{j}}-U_{\mathrm{a}}\right)$.

baroclinic, (b) in case of a cold front, the cold air mass typically penetrates below the warm air mass, building a stably stratified layer in between, which favours the generation of inertial oscillations, and (c) wind in the cold air mass is very often gusty (Wallace and Hobbs, 2006). LLJs developing in advance of cold fronts have been well documented in the literature (Browning and Harrold, 1970; Browning and Pardoe, 1973; Roux et al., 1993; Wakimoto and Murphey, 2008). Hence, the occurrence of a LLJ within a frontal zone suggests that some of the above-mentioned generation mechanisms have been responsible for it.

To detect fronts, we utilized the tethersonde soundings and surface-layer meteorological observations as well as the ECMWF operational analyses. In five LLJ cases, the 6hourly ECMWF analyses showed a front within a distance of about $800 \mathrm{~km}$ of Tara. All these LLJ cases were above classified as generated by (a) baroclinicity, (b) inertial oscillations or (c) gusts. In four of the cases, the front was clearly observed to pass over Tara. In the fifth case, according to the ECMWF analyses the front did not pass over Tara but nearby, and the wind blew parallel to the isobars with cold air on the right of the wind vector, generating ideal conditions for a baroclinic jet (as it was classified on the basis of the temperature gradient). In addition to the fronts detectable from the ECMWF analyses, during days with a LLJ observed, seven weaker frontal passages were observed at Tara, seen as rapid changes in the wind, air temperature, air humidity and radiative fluxes. As many as 17 LLJs were observed during these frontal passages but not classified as generated by baroclinicity, inertial oscillations or gusts. This suggests that in each case one or more of these mechanisms contributed to the generation of the LLJ. The high number of such frontal LLJs is partly due to the fact that four frontal passages were observed in four days with frequent soundings.

\subsection{Summary of generation mechanisms}

To summarize the potential forcing mechanisms for the 43 LLJs observed, 13 cases suggested baroclinicity ( 3 of them also potentially inertial oscillation), four cases suggested non-baroclinic inertial oscillations, and four could have been related to wind gusts. As many as 21 LLJs were associated with observed frontal passages. Among these cases, two were classified as baroclinic on the basis of the ECMWF air temperature gradients and two were generated potentially by inertial oscillation. In the other 17 frontal cases, baroclinicity, inertial oscillations, and/or gusts may have played a role in the jet generation. We note that seven of these frontal LLJs occurred within $6 \mathrm{~h}$ from a case classified as baroclinic. Bearing in mind the uncertainties in the pressure analyses in the central Arctic (Inoue et al., 2009; Tetzlaff et al., 2013), this suggests the contribution of baroclinicity. Only in five of the 43 cases the generation mechanism remained entirely unclear, but in these cases the jet strength was weak, only from 2.1 to $3.1 \mathrm{~m} \mathrm{~s}^{-1}$.

\section{Properties of low-level jets}

To count the properties of LLJs, 25 cases were included (see Sect. 2.2). The results are classified on the basis of the 


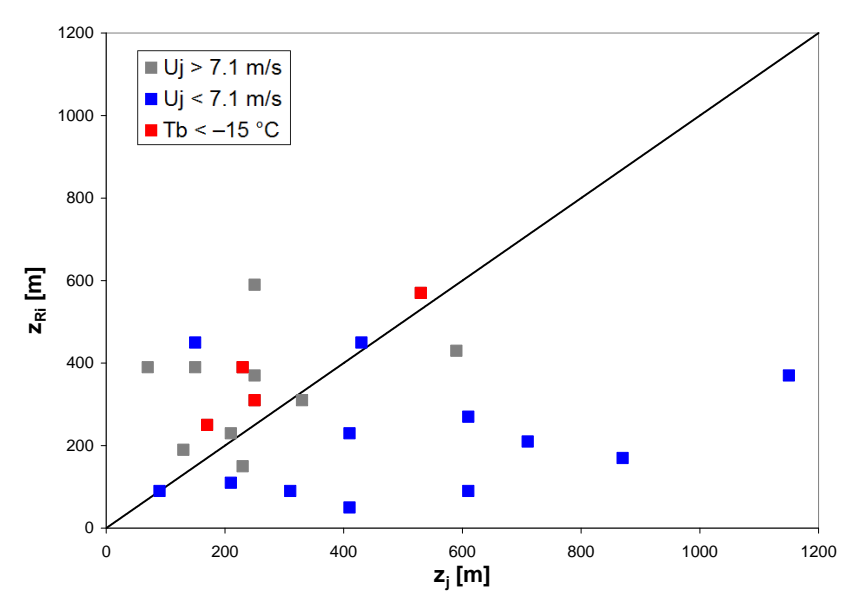

Fig. 7. A comparison of the height of the jet core, $z_{\mathrm{j}}$, and height of the turbulent layer, $z_{R i}$. LLJs are divided into groups of higher and lower than average $U_{\mathrm{j}}$. Also four cases are shown where the inversion base temperature $\left(T_{\mathrm{b}}\right)$ is less than $-15^{\circ} \mathrm{C}$ (these cases belong to the higher $U_{\mathrm{j}}$ group).

forcing mechanism, whereas class others includes cases with frontal passage and the five cases that remained entirely unclear. The jet core typically occurred at a height of 100$500 \mathrm{~m}$ (Fig. 6a), but the lowest one was observed at $70 \mathrm{~m}$ and highest at $1150 \mathrm{~m}$ altitude. On average, baroclinic jets were located lower and jets generated by gust higher than the others (Fig. 6a).

The most common depth of a jet was 400 to $600 \mathrm{~m}$ (Fig. 6b); only two sounding profiles showed a jet depth exceeding $1 \mathrm{~km}$. Almost half of the jets with a depth exceeding $700 \mathrm{~m}$ were baroclinic (Fig. 6b). The average jet core wind speed $\left(U_{\mathrm{j}}\right)$ was $7.1 \mathrm{~m} \mathrm{~s}^{-1}$ (Fig. $6 \mathrm{c}$; note that measurements were carried out only during winds lower than $15 \mathrm{~m} \mathrm{~s}^{-1}$ ). The change in the wind speeds between the jet core and the subsequent minimum (strength of the jet) was less than $3.0 \mathrm{~m} \mathrm{~s}^{-1}$ in $44 \%$ of the cases and stronger than $4.0 \mathrm{~m} \mathrm{~s}^{-1}$ in $28 \%$ of the cases (Fig. 6d). Jets with the highest $U_{\mathrm{j}}$ were not the strongest ones. Many jets of class others had a larger $U_{\mathrm{j}}$ than average (Fig. 6c) but a weaker jet: only in a single case was a jet stronger than $4 \mathrm{~m} \mathrm{~s}^{-1}$ (Fig. 6d). The average jet strength of entirely unclear forcing mechanism cases was only $2.5 \mathrm{~m} \mathrm{~s}^{-1}$ (not separately shown in figure). If all soundings had reached the height of $2 \mathrm{~km}$, there might have been some more cases of a stronger and deeper jet.

Considering all 25 jets, there was no correlation $(r=0.004)$ between the height of the jet core $\left(z_{\mathrm{j}}\right)$ and $z_{R i}$ (Fig. 7). However, the four soundings with inversion base temperatures $\left(T_{\mathrm{b}}\right)$ lower than $-15^{\circ} \mathrm{C}$ showed a high correlation $(r=0.95 ; p=0.052)$. Sounding data showed that a jet core with higher than average wind speed $\left(U_{\mathrm{j}}>7.1 \mathrm{~m} \mathrm{~s}^{-1}\right)$ occurred more often inside the turbulent layer (Fig. 7) (77\% of these cases showed $\left.z_{\mathrm{j}}<z_{R i}\right)$. Jet cores with smaller than average wind speed $\left(U_{\mathrm{j}}<7.1 \mathrm{~m} \mathrm{~s}^{-1}\right)$ appeared above the tur-

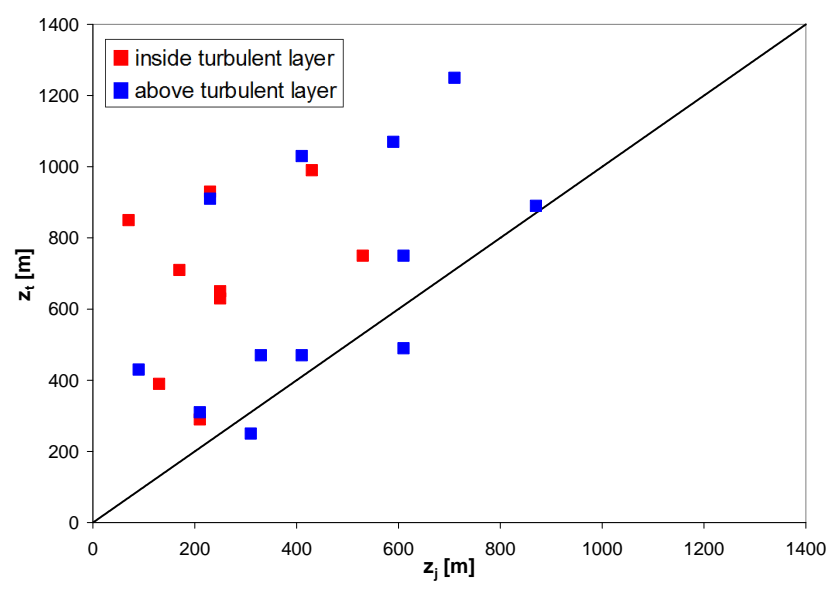

Fig. 8. A comparison of the height of the jet core, $z_{j}$, with the height of temperature inversion top, $z_{\mathrm{t}}$. LLJs are divided into two groups with the core inside or outside the turbulent layer.

bulent layer ( $83 \%$ of these cases showed $z_{\mathrm{j}}>z_{R i}$ ). A significant correlation $(r=0.61 ; p<0.01)$ was observed between $U_{\mathrm{j}}$ and $z_{R i}$. As the wind speed squared is a denominator in $\operatorname{Ri}(z)$, the stronger the wind the smaller the $\operatorname{Ri}(z)$, and the smaller the $\operatorname{Ri}(z)$ the higher the $z_{R i}$. Among the LLJs with higher than average wind speed, $38 \%$ were baroclinic, whereas only $25 \%$ of LLJs with smaller than average wind speed were baroclinic (Fig. 6c).

Also the jet core height and the height of the top of temperature inversion $z_{\mathrm{t}}$ correlated $(r=0.62 ; p<0.01 ;$ Fig. 8). LLJs with the core inside the turbulent layer had no significant correlation with $z_{\mathrm{t}}$, LLJs with the core above the turbulent layer had a correlation coefficient of $0.72(p<0.01)$. The lower was the inversion base temperature $\left(T_{\mathrm{b}}\right)$, the higher was $U_{\mathrm{j}}$ $(r=-0.64 ; p<0.01)$.

\section{Air mass origin}

The $72 \mathrm{~h}$ backward trajectory calculations for the $25 \mathrm{LLJ}$ cases observed (maximum one per day) showed that in most cases the air mass included a LLJ originating from the sea ice zone, with only seven cases from the open ocean. Even during these seven cases the air mass had traveled $800-1300 \mathrm{~km}$ over sea ice, as Tara was close to the North Pole.

The air mass origin (Fig. 9) was divided into five sectors: (1) $20^{\circ} \mathrm{W}-30^{\circ} \mathrm{E}$ (Fram Strait region), (2) $30-165^{\circ} \mathrm{E}$ (Russian Arctic), (3) $165-210^{\circ} \mathrm{E}$ (region towards the Bering Strait), (4) $210-340^{\circ} \mathrm{E}$ (western Arctic), and (5) vicinity of the North Pole (northward of $85^{\circ} \mathrm{N}$ ). All LLJs originating from the Fram Strait region (four cases) were located inside the turbulent layer $\left(z_{\mathrm{j}}<z_{R i}\right)$ whereas all LLJs originating from the Russian Arctic (five cases) were located above the turbulent layer $\left(z_{\mathrm{j}}>z_{R i}\right)$. There was not a statistically significant difference between $z_{\mathrm{j}}$ of these groups, but the mean $z_{R i}$ of the Russian sector ( $174 \mathrm{~m}$ ) was only $50 \%$ of that of the 


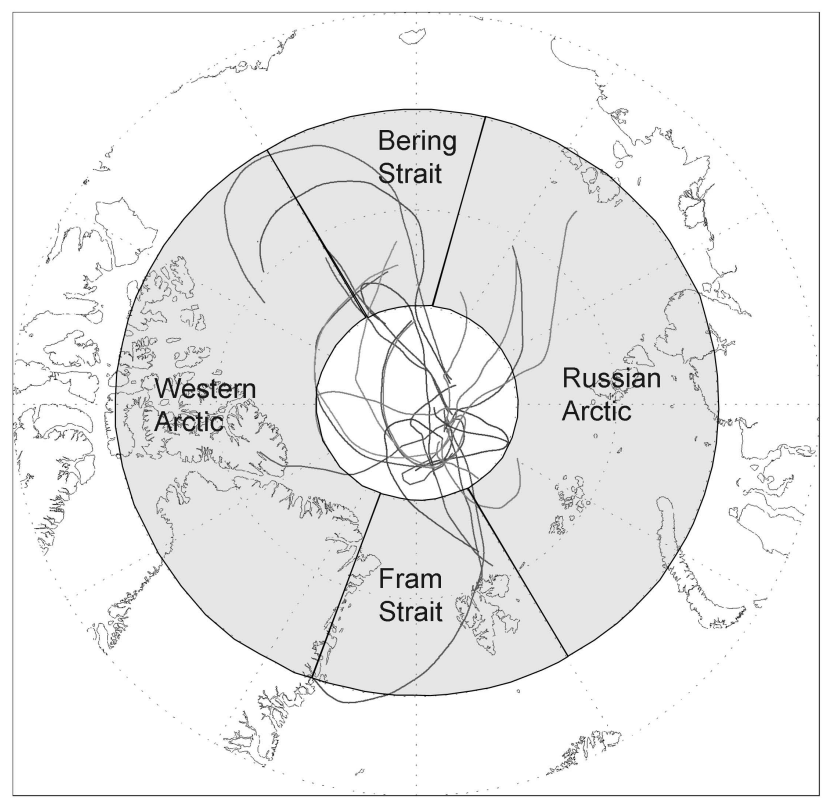

Fig. 9. $72 \mathrm{~h}$ backward trajectories (black curves) for 25 LLJs observed at Tara. The air mass origins are divided into sectors: Fram Strait, Russian Arctic, Bering Strait, Western Arctic and the sector in the vicinity of the North Pole (northward of $85^{\circ} \mathrm{N}$ ).

Fram Strait sector $(p<0.05)$. In all cases of the Fram Strait sector, the air mass had been over the open sea less than $72 \mathrm{~h}$ before the LLJ was observed at Tara. In only one case of the Russian sector, the air mass had been over the open sea less than $72 \mathrm{~h}$ (in this case $z_{\mathrm{j}}$ was only $20 \mathrm{~m}$ higher than $z_{R i}$ ). The fifth sector included six cases and showed some differences from the other LLJs. The average jet depth of $803 \mathrm{~m}$ was as much as $356 \mathrm{~m}$ larger $(p<0.05)$ than in the case of other jets, and the mean $z_{\mathrm{a}}$ of $1390 \mathrm{~m}$ was $631 \mathrm{~m}$ higher $(p<0.01)$ than in the case of other LLJs.

Soundings with LLJ cases had twice as many western Arctic air masses and almost half the Russian Arctic air masses than soundings without LLJ.

\section{Discussion and conclusions}

The Tara tethersonde soundings probably represent the best data set of LLJs over the central Arctic Ocean from April through August (although late summer has been better covered by ship-based observations, Tjernström et al., 2012). The new results of the study include the following: (a) a rather low occurrence of LLJs, (b) properties of LLJs related to baroclinicity: a low core height but often a deep jet, (c) the fact that about half of the LLJs were associated with a frontal passage, and (d) the fact that some LLJs are simply due to gusts, which cannot be diagnosed on the basis of standard radiosonde soundings.
The Tara results indeed showed a lower occurrence of LLJs (46 $\pm 8 \%$ ) compared to $80 \%$ of Andreas et al. (2000) over the Antarctic sea ice. Also ReVelle and Nilsson (2008) suggested a high occurrence of LLJs (60-80\%) over polar oceans, and Vihma et al. (1998) observed that $91 \%$ of rawinsonde soundings in the very baroclinic ice-edge zone in the Denmark Strait included a LLJ. According to our understanding, the most important reasons for the relatively low occurrence of LLJs at Tara were that (a) the observations were made far from strongly baroclinic zones, such as the sea ice margin, and (b) the typical conditions in AprilAugust were not as stably stratified as in the autumn-winter data set of Andreas et al. (2000). Another data with a low occurrence of LLJs $(25 \%)$ were the Arctic Ocean Expedition 2001 soundings, which were taken far from the ice edge (Tjernström et al., 2004).

Jets with a high $U_{\mathrm{j}}$ occurred mostly inside the turbulent layer, and jets with a low $U_{\mathrm{j}}$ above the turbulent layer. Strong jet core winds contribute to growth of the turbulent layer, i.e., there is a two-way interaction between the ABL structure and LLJs. Previous studies have indicated some correlation between the jet core height $z_{\mathrm{j}}$ and the temperature inversion top height $z_{\mathrm{t}}(r=0.53$ in a climatology of LLJs over the USA, Bonner, 1968). We detected a more complex relationship: if the jet core was inside the turbulent layer, there was no significant correlation between $z_{\mathrm{j}}$ and $z_{\mathrm{t}}$, whereas $r=0.72$ $(p<0.01)$ was observed for cases with the jet core above the turbulent layer. This is probably related to the common situation that in conditions of a strong temperature inversion, the turbulent layer is thin and inertial oscillations prevail, generating a jet close to $z_{\mathrm{t}}$.

Our results for the typical jet core height (100-500 m) fit well with those of the Arctic Ocean Expedition 2001 (Tjernström, 2004), where the jet core typically occurred at the height of $200-400 \mathrm{~m}$, whereas the core wind speeds were smaller $\left(5-7 \mathrm{~m} \mathrm{~s}^{-1}\right)$ than in our data $\left(7.1 \mathrm{~m} \mathrm{~s}^{-1}\right)$. The latter is somewhat surprising, as our data set was restricted to conditions of weak and moderate winds allowing tethersonde operation. A reason for the lower winds in Tjernström (2004) might be related to the limited temporal resolution of the radiosonde GPS system together with smoothing of the data, which may reduce the detection of extreme values occurring in thin layers. Also, similarly to the observations of Tjernström et al. (2004) and Andreas et al. (2000) over sea ice, we found the LLJ cores commonly within the temperature inversion layer (Fig. 8). In the observations of Vihma et al. (2011) over Svalbard fjords, LLJs were typically located above the top of the temperature inversion. These contrasting results were probably due to orographic effects.

According to Andreas et al. (2000), $z_{\mathrm{j}}$ and $z_{R i}$ agree very well. In our study, only the four cases with inversion base temperatures $\left(T_{\mathrm{b}}\right)$ under $-15^{\circ} \mathrm{C}$ showed a significant correlation $(r=0.95 ; p=0.05)$. Our measurements were carried out in spring and summer, whereas those of Andreas et al. (2000) were taken in autumn and winter. In their data set, 
the temperature at the inversion base was less than $-15^{\circ} \mathrm{C}$ most of the time. Walter and Overland (1991) detected a LLJ during a research aircraft flight near the location of the last sounding site of Tara. It is noteworthy that this cold-season LLJ was located at the top of the slightly stable layer just below the level where the Richardson number became very large, fitting very well to our population of cases with temperature less than $-15^{\circ} \mathrm{C}$ (Fig. 7).

Almost half of the LLJs observed were associated with frontal passages. In these cases the causal reason for the jet generation was probably baroclinicity, inertial oscillations or gusts. Considering cases when the potential causal mechanism was more clearly identified, the most important mechanism was baroclinicity, but also cases related to (potential) inertial oscillations, and gusts were detected. We are not aware of any previous study on LLJ generation mechanisms taking gusts into account. The inertial oscillations were probably due to synoptic-scale changes in stratification, as in Andreas et al. (2000). Our study differed from many previous studies on LLJs in the sense that the role of diurnal cycle was not detected, as the observations were made at latitudes $86-89^{\circ} \mathrm{N}$. Although not in LLJs, Tjernström et al. (2004) detected, however, subtle signs of diurnal cycle in the turbulence spectra at latitudes $88-89^{\circ} \mathrm{N}$.

Baroclinicity was responsible for generation of strong and warm LLJs, the former as in Vihma et al. (1998). Baroclinicity was a more important forcing mechanism in July and August (11 cases) than in April-June (two cases). The baroclinicity generating LLJs was mostly associated with transient cyclones, not with the climatological air temperature gradients. Accordingly, the July-August maximum may be related to the fact that in the central Arctic cyclones are more common (albeit weak) in summer than in any other season (Serreze and Barrett, 2008). In spring, the largest climatological temperature gradients occur over the sea ice margins, but Tara was far from these regions. Contrary to previous studies (Smedman et al., 2001), in the Tara data the baroclinic jets occurred at lower altitudes than other jets. As suggested by a reviewer, this is probably due to the fact that the core height of a baroclinic LLJ is determined by the frictional retardation of the stronger geostrophic winds below, and the frictionally affected layer is shallow under stable stratification, which is common over the Arctic sea ice. The baroclinicity itself may occur in a deep layer, as suggested by the fact that the jet depth was often large in the baroclinic cases.

The ECMWF analyses, as any model analyses, are naturally liable to errors in the central Arctic (Jakobson et al., 2012). We used the ECMWF fields primarily for the analyses of baroclinicity. A sufficiently large horizontal temperature gradient is needed to generate a baroclinic LLJ, and it is more likely that ECMWF analyses catch such synoptic-scale features than minor spatial gradients in the ABL. The latter may be generated, e.g. by surface heating over areas of reduced sea ice concentration (e.g. Vihma, 1995; Lüpkes et al., 2008). These are not necessarily reproduced by the ECMWF analyses, because the information on sea ice concentration is seldom accurate enough (Valkonen et al., 2008) and north of $84^{\circ} \mathrm{N}$ the sea ice concentration in the analyses was set to a constant value of $100 \%$, which was far from truth in summer 2007 (Comiso et al., 2008). If the sea ice zone includes large areas of open water that are not present in the ECMWF ice concentration field, a LLJ may also be generated via a spatial change in stratification and roughness (Vihma et al., 2003).

Further research needs on LLJs in the Arctic include investigation of low-level jet streams (Stensrud, 1996) and their effects on the sea ice drift and atmospheric moisture transport.

Acknowledgements. We thank the captain and crew of Tara for their highly valuable contributions to the field work. This study was supported by the DAMOCLES project, funded by the European Commission in the 6th Framework Programme for Research and Development (contract 018509). The work of TV was also supported by the Academy of Finland through the CACSI project (contract 259537). The ECMWF is acknowledged for providing us with model results. We thank two anonymous reviewers for their constructive comments which helped to improve the manuscript.

Edited by: K. Dethloff

\section{References}

Andreas, E. L., Claffey, K. J., and Makshtas, A. P.: Low-Level Atmospheric Jets and Inversions over the Weddell Sea, Bound.-Lay. Meteorol., 97, 459-486, doi:10.1023/A:1002793831076, 2000.

Atlaskin, E. and Vihma, T.: Evaluation of NWP results for wintertime nocturnal boundary-layer temperatures over $\mathrm{Eu}$ rope and Finland, Q. J. Roy. Meteor. Soc., 138, 1440-1451, doi:10.1002/qj.1885, 2012.

Blackadar, A. K.: Boundary layer wind maxima and their significance for the growth of nocturnal inversions, B. Am. Meteorol. Soc., 38, 283-290, 1957.

Bonner, W.: Climatology of the low level jet, Mon. Weather Rev., 96, 833-850, doi:10.1175/15200493(1968)096<0833:COTLLJ>2.0.CO;2, 1968.

Browning, K. A. and Harrold, T. W.: Air motion and precipitation growth at a cold front, Q. J. Roy. Meteor. Soc., 96, 369-389, doi:10.1002/qj.49709640903, 1970.

Browning, K. A. and Pardoe, C. W.: Structure of low-level jet streams ahead of mid-latitude cold fronts, Q. J. Roy. Meteor. Soc., 99, 619-638, doi:10.1002/qj.49709942204, 1973.

Christensen, J. H., Hewitson, B., Busuioc, A., Chen, A., Gao, X., Held, I., Jones, R., Kolli, R. K., Kwon, W.-T., Laprise, R., Magaña Rueda, V., Mearns, L., Menéndez, C. G., Räisänen, J., Rinke, A., Sarr, A., and Whetton, P.: Regional Climate Projections, in: Climate Change 2007: The Physical Science Basis. Contribution of Working Group I to the Fourth Assessment Report of the Intergovernmental Panel on Climate Change, edited by: Solomon, S., Qin, D., Manning, M., Chen, Z., Marquis, M., Averyt, K. B., Tignor, M., and Miller, H. L., Cambridge University Press, Cambridge, United Kingdom and New York, NY, USA, 2007. 
Comiso, J. C., Parkinson, C. L., Gersten, R., and Stock, L.: Accelerated decline in the Arctic sea ice cover, Geophys. Res. Lett., 35, L01703, doi:10.1029/2007GL031972, 2008.

Costa, F. D., Acevedo, O. C., Mombach, J. C. M., and Degrazia, G. A.: A Simplified Model for Intermittent Turbulence in the Nocturnal Boundary Layer, J. Atmos. Sci., 68, 1714-1729. doi:10.1175/2011JAS3655.1, 2011.

Esau, I. and Repina, I.: Wind Climate in Kongsfjorden, Svalbard, and Attribution of LeadingWind DrivingMechanisms through Turbulence-Resolving Simulations, Advances in Meteorology, 2012, 568454, doi:10.1155/2012/568454, 2012.

Galperin, B., Sukoriansky, S., and Anderson, P. S.: On the critical Richardson number in stably stratified turbulence, Atmos. Sci. Lett., 8, 65-69, doi:10.1002/asl.153, 2007.

Gascard, J.-C., Festy, J., Goff, H., Weber, M., Brümmer, B., Offermann, M., Doble, M., Wadhams, P., Forsberg, R., Hanson, S., Skourup, H., Gerland, S., Nicolaus, M., Metaxian, J.-P., Grangeon, J., Haapala, J., Rinne, E., Haas, C., Wegener, A., Heygster, G., Jakobson, E., Palo, T., Wilkinson, J., Kaleschke, L., Claffey, K., Elder, B., and Bottenheim, J.: Exploring Arctic Transpolar Drift During Dramatic Sea Ice Retreat, Eos Trans. AGU, 89, 21-22, doi:10.1029/2008EO030001, 2008.

Heinemann, G.: Local Similarity Properties of the Continuously Turbulent Stable Boundary Layer over Greenland, Bound.-Lay. Meteorol., 112, 283-305, doi:10.1023/B:BOUN.0000027908.19080.b7, 2004.

Inoue, J., Enomoto, T., Miyoshi, T., and Yamane, S.: Impact of observations from Arctic drifting buoys on the reanalysis of surface fields, Geophys. Res. Lett., 36, L08501, doi:10.1029/2009GL037380, 2009.

Jakobson, E., Vihma, T., Palo, T., Jakobson, L., Keernik, H., and Jaagus, J.: Validation of atmospheric reanalyses over the central Arctic Ocean, Geophys. Res. Lett., 39, L10802, doi:10.1029/2012GL051591, 2012.

Kaimal, J. C. and Finnigan, J. J.: Atmospheric boundary layer flows: their structure and measurement, Oxford University Press, 1994.

Langland, R. H., Tag, P. M., and Fett, R. W.: An ice breeze mechanism for boundary-layer jets, Bound.-Lay. Meteorol., 48, 177195, 1989.

Lüpkes, C., Vihma, T., Birnbaum, G., and Wacker, U.: Influence of leads in the sea ice on the temperature of the atmosphere boundary layer during polar night, Geophys. Res. Lett., 35, L03805, doi:10.1029/2007GL032461, 2008.

Lüpkes, C., Vihma, T., Jakobson, E., König-Langlo, G., and Tetzlaff, A.: Meteorological observations from ship cruises during summer to the central Arctic: A comparison with reanalysis data, Geophys. Res. Lett., 37, L09810, doi:10.1029/2010GL042724, 2010.

Mahrt, L.: Stably stratified boundary layer, in: Encyclopedia of Atmospheric Sciences, edited by: Holton, J. P., Curry, J. A., and Pyle, J., Academic Press, London, 298-305, 2002.

Maksimovich, E. and Vihma, T.: The effect of surface heat fluxes on interannual variability in the spring onset of snow melt in the central Arctic Ocean, J. Geophys. Res. 117, C07012, doi:10.1029/2011JC007220, 2012.

Mäkiranta, E., Vihma, T, Sjöblom, A., and Tastula, E.-M.: Observations and modelling of the atmospheric boundary layer over sea ice in a Svalbard fjord, Bound.-Lay. Meteorol., 140, 105-123, doi:10.1007/s10546-011-9609-1, 2011.
Revelle, D. O. and Nilsson, E. D.: Summertime Low-Level Jets over the High-Latitude Arctic Ocean, J. Appl. Meteorol. Clim., 47, 1770-1784, doi:10.1175/2007JAMC1637.1, 2008.

Roux, F., Marécal, V., and Hauser, D.: The 12/13 January 1988 narrow cold-frontal rainband observed during MFDP/ FRONTS 87. Part I: Kinematics and thermodynamics, J. Atmos. Sci., 50, 951974, 1993.

Samelson, R. M. and Barbour, P. L.: Low-Level Jets, Orographic Effects, and Extreme Events in Nares Strait: A Model-Based Mesoscale Climatology, Mon. Weather Rev., 136, 4746-4759, doi:10.1175/2007MWR2326.1, 2008.

Serreze, M. C. and Barrett, A. P.: The Summer Cyclone Maximum over the Central Arctic Ocean, J. Climate, 21, 1048-1065. doi:10.1175/2007JCLI1810.1, 2008.

Smedman, A.-S., Tjernstróm, M., and Högström, U.: Analysis of the Turbulence Structure of a Marine Low-Level Jet, Bound.Lay. Meteorol., 66, 105-126, 1993.

Smedman, A.-S., Andre, U., Carlsson, M., Högström, U., Magnusson, M., Rost, J., and Zilitinkevich, S.: Surface-layer turbulence and the structure of the atmospheric boundary layer, in: BALTEX-BASIS Final Report, edited by: Launiainen, J. and Vihma, T., International BALTEX Secretariat, Publication, No. 19, p. 219, Geesthacht, Germany, 14-41, 2001.

Steeneveld, G. J., van de Wiel, B. J. H., and Holtslag, A. A. M.: Modelling the Arctic stable boundary layer and its coupling to the surface, Bound.-Lay. Meteorol., 118, 357-378, doi:10.1007/s10546-005-7771-z, 2006.

Stensrud, D.: Importance of low-level jets to climate: a review, J. Climate, 9, 1698-1711, 1996.

Stroeve, J., Holland, M. M., Meier, W., Scambos, T., and Serreze, M.: Arctic sea ice decline: Faster than forecast, Geophys. Res. Lett., 34, L09501, doi:10.1029/2007GL029703, 2007.

Stroeve, J. C., Serreze, M. C., Holland, M. M., Kay, J. E., Malanik, J., and Barrett, A. P.: The Arctic's rapidly shrinking sea ice cover: a research synthesis, Climate Change, 110, 1005-1027, doi:10.1007/s10584-011-0101-1, 2012.

Stull, R.: An Introduction to Boundary Layer Meteorology, Springer, 670 pp., 1988.

Stull, R.: Micrometeorology, Eos Trans. AGU, 90, 7, doi:10.1029/2009EO010010, 2009.

Suomi, I., Vihma, T., Gryning, S.-E., and Fortelius, C.: Wind gust parameterizations at heights relevant for wind energy - a study based on mast observations, Q. J. Roy. Meteor. Soc., 138, 12981310, doi:10.1002/qj.2039, 2012.

Tetzlaff, A., Kaleschke, L., Lüpkes, C., Ament, F., and Vihma, T.: The impact of heterogeneous surface temperatures on the 2-m air temperature over the Arctic Ocean under clear skies in spring, The Cryosphere, 7, 153-166, doi:10.5194/tc-7-153-2013, 2013.

Thorpe, A. J. and Guymer, T. H.: The nocturnal jet, Q. J. Roy. Meteor. Soc., 103, 633-653, 1977.

Tjernström, M., Leck, C., Persson, P. O. G., Jensen, M. L., Oncley, S. P., and Targino, A.: The Summertime Arctic Atmosphere: Meteorological Measurements during the Arctic Ocean Experiment 2001, B. Am. Meteorol. Soc., 85, 1305-1321, 2004.

Tjernström, M., Žagar, M., Svensson, G., Cassano, J., Pfeifer, S., Rinke, A., Wyser, K., Dethloff, K., Jones, C., Semmler, T., and Shaw, M.: Modelling the Arctic Boundary Layer: An Evaluation of Six Arcmip Regional-Scale Models using Data 
from the Sheba Project, Bound.-Lay. Meteorol., 117, 337-381, doi:10.1007/s10546-004-7954-z, 2005.

Tjernström, M., Birch, C. E., Brooks, I. M., Shupe, M. D., Persson, P. O. G., Sedlar, J., Mauritsen, T., Leck, C., Paatero, J., Szczodrak, M., and Wheeler, C. R.: Meteorological conditions in the central Arctic summer during the Arctic Summer Cloud Ocean Study (ASCOS), Atmos. Chem. Phys., 12, 6863-6889, doi:10.5194/acp-12-6863-2012, 2012.

Uttal, T., Curry, J. A., McPhee, M. G., Perovich, D. K., Moritz, R. E., Maslanik, J. A., Guest, P. S., Stern, H. L., Moore, J. A., Turenne, R., Heiberg, A., Serreze, M. C., Wylie, D. P., Persson, O. G., Paulson, C. A., Halle, C., Morison, J. H., Wheeler, P. A., Makshtas, A., Welch, H., Shupe, M. D., Intrieri, J. M., Stamnes, K., Lindsey, R. W., Pinkel, R., Pegau, W. S., Stanton, T. P., and Grenfeld, T. C.: Surface Heat Budget of the Arctic Ocean, B. Am. Meteorol. Soc., 83, 255-275, doi:10.1175/15200477(2002)083<0255:SHBOTA>2.3.CO;2, 2002.

Valkonen, T., Vihma, T., and Doble, M.: Mesoscale modelling of the atmospheric boundary layer over the Antarctic sea ice: a late autumn case study, Mon. Weather Rev., 136, 1457-1474, 2008.

Vihma, T.: Subgrid parameterization of surface heat and momentum fluxes over polar Oceans, J. Geophys. Res., 100, 22625-22646, 1995.

Vihma, T. and Brümmer, B.: Observations and modelling of the onice and off-ice air flow over the northern Baltic Sea, Bound.-Lay. Meteorol., 103, 1-27, doi:10.1023/A:1014566530774, 2002.

Vihma, T., Uotila, J., and Launiainen, J.: Air-sea interaction over a thermal marine front in the Denmark Strait, J. Geophys. Res., 103, 27665-27678, doi:10.1029/98JC02415, 1998.
Vihma, T., Hartmann, J., and Lüpkes, C.: A case study of an onice air flow over the Arctic marginal sea ice zone, Bound.-Lay. Meteorol., 107, 189-217, doi:10.1023/A:1021599601948, 2003.

Vihma, T., Jaagus, J., Jakobson, E., and Palo, T.: Meteorological conditions in the Arctic Ocean in spring and summer 2007 as recorded on the drifting ice station Tara, Geophys. Res. Lett., 35, L18706, doi:10.1029/2008GL034681, 2008.

Vihma, T., Kilpeläinen, T., Manninen, M., Sjöblom, A., Jakobson, E., Palo, T., Jaagus, J., and Maturilli, M.: Characteristics of temperature and humidity inversions and low-level jets over Svalbard fjords in spring, Advances in Meteorology, 2011, 486807, doi:10.1155/2011/486807, 2011.

Wakimoto, R. M. and Murphey, H. V.: Airborne Doppler Radar and Sounding Analysis of an Oceanic Cold Front, Mon. Weather Rev., 136, 1475-1491, doi:10.1175/2007MWR2241.1, 2008.

Wallace, J. M. and Hobbs, P. V.: Atmospheric Science - An Introductory Survey, 2nd edition, Academic Press, p. 483, 2006.

Walsh, J. E., Overland, J. E., Groisman, P. Y., and Rudolf, B.: Ongoing climate change in the Arctic, Ambio, 40, 6-16, doi:10.1007/s13280-011-0211-z, 2011.

Walter, B. and Overland, J. E.: Aircraft Observations of the Mean and Turbulent Structure of the Atmospheric Boundary Layer During Spring in the Central Arctic, J. Geophys. Res., 96, 46634673, doi:10.1029/90JC02263, 1991. 